revenue by supplying the Colony's ordinary woodconsuming industries with local timber. Some of this high revenue is in reality trust capital and strictly. speaking ought to be treated as such."

\section{Nature Protection in Poland}

DURING its spring session, the Parliament of Poland discussed and passed a new law for the protection of Nature, a comprehensive measure covering many objects (Kwartalny Biuletyn Informacyjny, 4 ; 1934). The threat of the erection of tourist mountain railways on the Polish, as well as on the Czechoslovakian, side of the Tatras has aroused much concern and opposition, for it would interfere with the object, which seemed to be on the point of fulfilment, of creating a grand Tatras National Park jointly cared for by Poland and Czechoslovakia. In the eastern Carpathians, there has been created by the Metropolitan of the Greek-Catholic Church, a new Nature reserve, interesting because it protects a fine forest of Cembro pines (Pinus Cembra) growing upon the summit of Mount Jajko. Indeed the protection of ancient trees is one of the features of the Polish scheme, and one of the most remarkable grows in the village of Harbutowice in the west Carpathians - the oldest yew in the country, having a circumference of 2.80 metres. An excellent step has been taken in enlisting the co-operation of the school authorities in the Cracow and other districts; and with the object of familiarising school teachers with the objects and methods of Nature protection, special conferences have been held at which discussions have taken place on the feeding of birds in winter, and on the plants specially protected in the school districts. Another step, which might well be copied in Great Britain, is the agreement come to with the Polish radio authorities arranging that talks will be broadcast once a month on different aspects of the protection of Nature.

\section{Activities of the Post Office}

THE last annual report of the Post Office was issued nearly twenty years ago. Since then, there have been many radical changes and important developments in the work of this Government department which are not yet well known. We therefore welcome "The Post Office, 1934" (London : G.P.O. 1s.) which has just been published. In the preface the Postmaster-General reviews some of the developments, and he may indeed be proud of his department, which has kept well abreast of all the latest scientific advances. Owing to the competition of telephony, the traffic handled by the telegraph service shows a considerable falling off, but the rapid and revolutionary changes introduced are checking this decline. The teleprinter is now the standard machine in use in Britain; Morse signalling is rarely used. A motor-cycle service has quickened delivery, and incoming liners are met by telegraph representatives. As an experiment, boy messengers are attending a few of the main railway stations to accept telegrams from outgoing passengers. Up to twenty years ago, the telegraph was the only means of communication with foreign countries; now a telephone subscriber in Great Britain can communicate with 95 per cent of the telephone subscribers of the world. Wonderful progress has been made with radio services. For broadcasting, unfortunately, the wave-length position in Europe is very difficult owing to the fact that there are far more broadcasting stations than there are wavelengths available for their use. Some countries were not satisfied with the allocation of wave-lengths made at the Lucerne Conference and are using waves contrary to the Lucerne plan.

\section{Electricity Development in France}

The aim of electrical engineers in France is to create a huge network of high-voltage transmission lines which will connect the generating stations with the great centres of consumption. The systems of transmission are being standardised. For the hightension lines, 220 and 150 kilovolts are being used, and secondary pressures of 90 and 60 are employed. This compares with the 132 kilovolts used in the British Grid. A report issued by the Department of Overseas Trade on "Economic Conditions in France" by Sir Robert Cahill (London: H.M. Stationery Office, $7 s$. net) gives much instructive information on this subject. It is stated that the production and distribution of electricity in France provide employment for 150,000 workers. The yearly output has been estimated at about one twentieth of the total world output. There are 1,200 companies producing or distributing electricity, and the productive capacity of the stations increased very rapidly before the commercial depression and is still increasing. The output of the great thermal stations of the coalmining, metallurgical and industrial areas, north and east of Paris, and in the vicinity of Lyons, will form in a few years' time part of a comprehensive electrical supply system, so that any temporary breakdown in the supply from one station can be made good from the others. The output of the thermal is double that of the hydro-electric stations. There still remains about 60 per cent of the maximum possible water-power not utilised. The Rhine development scheme includes the erection of eight large power stations at intervals along the river. The first, which is already in operation, is at Kembs, about ten miles below Basle, and is equipped to produce nearly 200,000 kilowatts. The combined power of the eight stations will be 650,000 kilowatts. Various schemes have been proposed and stations built for utilising tidal power on the coast of Brittany, but so far none of them seems to have been commercially successful.

\section{Social Insurance}

THE importance of demographic considerations in relation to social problems are stressed by Prof. J. P. Dalton in a pamphlet on "Social Insurance" recently published by the University of the Witwatersrand Press, Johannesburg. The author claims that the demographic consequences of social processes are in the long run of paramount importance, though they are usually ignored or ill-understood. He argues 